\title{
CUIDADOS PALIATIVOS E AUTONOMIA DO PACIENTE TERMINAL: REFLEXÕES SOBRE O TESTAMENTO VITAL NO BRASIL
}

\author{
PALLIATIVE CARE AND AUTONOMY OF THE TERMINAL PATIENT: \\ REFLECTIONS ON THE VITAL TESTAMENT IN BRAZIL
}

Taciana Damo Cervi'

A prova (...) da liberdade é inseparável da prova da mortalidade.

Nenhum ser - nem um indivíduo nem uma sociedade -

pode ser livre sem aceitar a mortalidade.

Cornelius Castoriadis

RESUMO: A pesquisa investiga o contexto em que se desenvolve o testamento vital no Brasil. Por meio da referida declaraçâo de vontade e após aconselhamento médico, a pessoa elege o que considera como digno em atendimento de saúde quando estiver em circunstâncias de terminalidade de vida. $O$ estudo se justifica em razăo da inexistência de legislaçăo sobre a matéria e da necessidade difundir o precedente gaúcho que reconheceu a ortotanásia ou o direito à morte digna por meio do testamento vital. A investigaçăo adota as teorias de Hegel e Honneth para contextualizar os anseios do paciente terminal na luta pelo reconhecimento. Inicialmente, o trabalho se dedica à abordagem da vulnerabilidade do paciente terminal e a relaçăo transparente que deve existir na prestaçăo de serviços médicos, identificando o instrumento como reflexo dos princípios bioéticos. Ainda, a investigaçăo se debruça sobre o que sejam as diretivas antecipadas de vontade, especialmente o testamento vital como declaraçăo de vontade para tratamentos de saúde em fim de vida. Em seguida, a pesquisa analisa o precedente gaúcho de reconhecimento da ortotanásia no qual restou demonstrado importante avanço do entendimento jurisprudencial acerca dos cuidados paliativos do paciente terminal. Ao final, verifica-se que oportunizar as pessoas a elaboraçăo de diretivas antecipadas de vontade constitui-se em condiçấo sine qua non para o reconhecimento e concretizaçấo da autonomia e liberdade do paciente terminal. 0 trabalho adota o método de procedimento monográfico com a pesquisa indireta e o método de abordagem dedutivo.

PALAVRAS-CHAVE: Cuidados paliativos. Autonomia. Testamento vital. Brasil.

1 Professora universitária. Doutoranda em Direito pela UFRGS. Assessora técnica do Comitê de Ética em Pesquisa com Humanos na URI, campus de Santo Ângel. taciana@san.uri.br 
ABSTRACT: The research investigates the context in which the living will is developed in Brazil. Through this declaration of will and after medical advice, the person elects what he considers to be worthy in health care when he is in terminal life circumstances. The study is justified by the inexistence of legislation on the matter and the need to disseminate the Gaucho precedent that recognized orthathanasia or the right to a dignified death through a living will. The research adopts Hegel and Honneth's theory to contextualize the terminal patient's longings in the struggle for recognition. Initially, the paper focuses on the vulnerability of the terminal patient and the transparent relationship that must exist in the provision of medical services, identifying the instrument as a reflection of bioethical principles. In addition, research focuses on anticipated will directives, especially the living will as a declaration of will for end-of-life health care. Next, the study analyzes the previous gaucho recognition of ortho- thasia in which it has been shown important advance of the jurisprudential understanding about palliative care of the terminal patient. In the end, it is verified that giving people the preparation of advance directives of will constitutes a sine qua non condition for the recognition and realization of the autonomy and freedom of the terminal patient. The work adopts the deductive method with indirect research.

KEYWORDS: Palliative care. Autonomy. Freedom. Living Will. Brazil.

\section{INTRODUÇÃO}

A ideia de realizar um estudo sobre o testamento vital surgiu da constataçăo do avanço da legislaçăo em outros países, especialmente na Espanha, e da inexistência de legislaçăo pátria para a temática e do precedente judicial gaúcho que reconheceu a legitimidade de uma pessoa optar pela morte digna a partir do testamento vital. 0 estudo se justifica em razăo de que o paciente Joăo Carlos Ferreira, idoso, deliberou sobre a ortotanásia ${ }^{2}$ por meio do denominado testamento vital.

Ainda que a nomenclatura testamento vital possa ser compreendida como inadequada, uma vez que a palavra testamento indica disposiçấo acerca de vontades para produçăo de efeitos post mortem, trata-se de expressăo amplamente utilizada no mundo todo e mais popularmente conhecida, de modo que por tais razôes assim é referida no trabalho aqui demonstrado.

O precedente judicial gaúcho insere no cenário jurídico brasileiro questăo abordada apenas academicamente carecendo de um marco regulatório. As buscas realizadas junto à Corte Suprema demonstram resultado algum, de modo que a análise do precedente busca identificar os argumentos aplicáveis.

O testamento vital figura no ordenamento jurídico brasileiro como contrato atípico e, nesse sentido, vem sendo interpretado de acordo com as diretrizes estabelecidas pela parte geral do Código Civil no que concerne a sua validade e eficácia.

Nesses termos, a pesquisa pretende contribuir para a reflexăo acerca da (in)viabilidade de um marco regulatório para a temática, tal qual pode ser verificado na Espanha.

2 Refere o artigo $1^{\circ}$ da Resoluçăo ${ }^{\circ} 1.805 / 2006$ do Conselho Federal de Medicina, "é permitido ao médico limitar ou suspender procedimentos e tratamentos que prolonguem a vida do doente em fase terminal, de enfermidade grave e incurável, respeitada a vontade da pessoa ou de seu representante legal". 
Para tanto, inicialmente o trabalho contextualiza a vulnerabilidade do paciente terminal e os cuidados paliativos decorrentes da implementaçāo dos princípios bioéticos. Posteriormente, aborda a relaçăo médico/paciente em um contexto de cumprimento da cláusula da boa-fé objetiva, dado que se trata de contrato de prestaçăo de serviços médicos. Por conseguinte, a pesquisa aborda as diretivas antecipadas de vontade, especialmente o testamento vital resgatando sua origem e propósitos. Na sequência, o estudo resgata a política hegeliana de reconhecimento para posteriormente abordar a perspectiva da liberdade em Honneth. Ao final, o estudo analisa as perspectivas para o tema no Brasil a partir do precedente gaúcho de reconhecimento da ortotanásia e o direito de morrer com dignidade.

O trabalho adota o método dedutivo por meio da abordagem indireta, com a consulta a livros, revistas e jurisprudência.

\section{VULNERABILIDADE DO PACIENTE TERMINAL E CUIDADOS PALIATIVOS}

A temática da morte, o enfrentamento do processo de morte e o sofrimento das pessoas é uma preocupaçăo constante da humanidade. Enquanto percebe-se imensa quantidade de trabalhos científicos, processos judiciais e esforços cotidianos para a preservaçáo da vida e a sobrevivência das pessoas, de outro lado existe movimento no sentido de refletir sobre o modo como tem-se oportunizado dignidade às pessoas nos momentos derradeiros de suas vidas.

O debate tem sido intensificado a partir dos avanços científicos concernentes à manutençăo artificial da vida pois, o que mais preocupa năo é o evento morte, e sim, o processo que conduz a esse momento final de extinçâo da personalidade que denota momento ímpar da vulnerabilidade humana.

O que se compreende com o termo vulnerabilidade? A partir do latim, vulnerabilis, que causa lesăo. Com isso, compreende-se que vulnerável é todo aquele que pode ser fisicamente ferido; atacado, prejudicado, ofendido. Historicamente, os vulneráveis eram compreendidos como os deficientes mentais e físicos, as crianças, os senis e os institucionalizados de qualquer ordem. Ao longo da história percebeu-se que também sâo vulneráveis e carecem de proteçâo as populaçôes subdesenvolvidas, as pessoas em vulnerabilidade social, fruto de contextos de opressăo e pobreza. (BARCHIFONTAINE, 2007, p.77).

O conceito de vulnerabilidade surgiu nos debates bioéticos nos anos de 1990 com o susto provocado pelo amplo crescimento da epidemia causada pelo vírus HIV. A partir de entăo, percebeu-se também que, mesmo pessoas economicamente privilegiadas seriam também vulneráveis e passíveis de serem contaminadas. (BARCHIFONTAINE, 2007, p.77). Entăo, a vulnerabilidade passa a ser identificada por dois modos: como caracterizaçăo de situaçăo de fragilidade particular por algumas pessoas e como condiçấo humana universal.

Por outro viés, Zancanaro refere a existência de dois momentos em que a vulnerabilidade se torna latente: no início e no final da vida. Em ambas as circunstâncias năo podemos encontrar autonomia, liberdade, mas sim, cuidado. No início da vida, o cuidado é incondicional, ou a vida do recém- nascido se torna inviável. No final da vida, 
o cuidado está relacionado à proteçăo dos direitos humanos e da dignidade dos doentes incuráveis e terminais. (ZANCANARO, 2007, p.58).

No tocante ao final de vida, percebe-se como circunstância de pleno significado. Estar junto da família, de amigos e animais queridos, assim como de objetos pessoais, em um ambiente acolhedor e confortante, sáo cuidados que devem ser dispensados ao doente em estado terminal. Garantir uma boa morte ou qualidade de vida nesse momento é imprescindível para a promoçáo do conforto do doente. Em verdade, uma garantia de dignidade no final da vida.

Os cuidados paliativos săo referidos desde 1990 pela Organizaçăo Mundial de Saúde-OMS, como toda a atençâo dada a pessoa no sentido de aliviar a dor, o sofrimento físico e emocional dos pacientes com enfermidades graves em fase avançada, ajudando ainda os familiares a cuidar dos seus entes queridos. De acordo com o primeiro mapa mundial das necessidades de cuidados paliativos divulgado pela OMS, em cada dez pacientes que necessitam de cuidados paliativos apenas um obtém tal atendimento. (ORGANIZAÇĀO MUNDIAL DE SAÚDE, 2018). As razôes de dada constataçăo seriam a ausência de políticas públicas de reconhecimento da assistência paliativa e também, o desconhecimento por parte dos profissionais de saúde, voluntários, comunidade e do público em geral sobre os benefícios dos cuidados paliativos.

Nesse aspecto, a atençấo na forma de cuidados paliativos deve acontecer sempre que estiver constatada terminalidade da vida, circunstância em que tratamentos supérfluos deixem de ser administrados. Existem critérios que determinam quando uma patologia pode ser considerada terminal, a Sociedade Espanhola de Cuidados Paliativos - SECPAL, traça os elementos seguintes: presença de uma doença avançada, progressiva e incurável; falta de possibilidades razoáveis de respostas a tratamentos específicos; verificaçăo de diversos sintomas, múltiplos, multifatoriais; grande impacto emocional no paciente, família e equipe de cuidados estritamente relacionado com a presença explícita ou náo da morte; e ainda, prognóstico de vida inferior a seis meses. (SOCIEDAD ESPAN̄OLA DE CUIDADOS PALIATIVOS, 2018).

De acordo com dados da Organizaçâo Mundial de Saúde para o ano de 2015, 40 milhóes de pessoas no mundo necessitaram de cuidados paliativos e, desse total, $78 \%$ se encontravam em países subdesenvolvidos ou em desenvolvimento, de modo que apenas $14 \%$ tiveram acesso a tais oportunidades. (ORGANIZAÇÂO MUNDIAL DE SAÚDE, 2018).

De acordo com o mesmo documento a necessidade por cuidados paliativos será crescente em razăo do processo de envelhecimento da populaçăo e a urgência pela assistência paliativa tempestiva é justificada em razăo da reduçăo das hospitalizaçóes e dos serviços de saúde.

Para tanto, González-Serna elenca cinco princípios éticos básicos para o enfrentamento das enfermidades diagnosticadas e relacionadas à terminalidade de vida para a correta implementaçăo da ortotanásia, compreendida como a estratégia de aplicaçáo dos meios adequados a garantir uma morte digna, respeitando o processo natural de morte. (GONZÁLEZ-SERNA, 2008, p.196).

Os princípios destacados pelo autor săo orientadores para a tomada de decisóes clínicas, sendo identificados pela solidariedade, năo maleficência, justiça, autonomia 
e beneficência. Quanto ao primeiro, o princípio da solidariedade, é compreendido pela aproximaçấo ao doente, calor humano, prestaçăo de cuidados paliativos e o alívio do sofrimento. No que pertine ao princípio da năo maleficência, consiste em náo causar danos ao ser humano e especialmente quanto ao doente terminal, significa utilizar medidas que propiciem qualidade de vida. (GONZÁLEZ-SERNA, 2008, p.197).

Quanto ao princípio da justiça, diz respeito a garantir à pessoa em estágio terminal o acesso aos tratamentos disponíveis sem discriminaçăo. Ainda, quanto ao princípio da autonomia, busca-se garantir a voluntariedade na aceitaçâo de tratamentos por meio da tomada de decisóes pelo próprio paciente ou, em casos de impossibilidade, por sua família. No que se refere ao princípio da beneficência, significa maximizar os benefícios previstos e minimizar os possíveis danos. (ZANCANARO, 2007, p.73).

Assim, denota-se que os princípios bioéticos visam proporcionar à pessoa o atendimento de suas necessidades, especialmente em circunstâncias de vulnerabilidade. Trata-se de compromisso ético dos profissionais de saúde no sentido de ajudar o paciente e sua família a assumir com resiliência o processo de morte, garantindo atençâo médica, espiritual, psicológica, respeitando nesse processo assistencial os valores e convicçôes do paciente.

\section{A PRESTAÇÃO DE SERVIÇO MÉDICO E A BOA-FÉ OBJETIVA}

Consagrada a autonomia da vontade como princípio bioético e a legitimidade da determinaçấo de tratamentos ou a dispensa de outros, surge o testamento vital como declaraçấo de vontade antecipada acerca das circunstâncias de terminalidade.

A elaboraçâo do testamento vital pressupóe o aconselhamento médico. Năo é possível que uma pessoa determine como quer morrer sem nem mesmo averiguar seu estado de saúde, quais suas predisposiçóes, o que a medicina pode informar-lhe acerca de doenças familiares. Nesse sentido, a escolha por determinados tratamentos e náo por outros, tem como pressuposto o esclarecimento médico relacionado as consequências das doenças para o paciente.

A autonomia somente pode ser considerada quando produto de aconselhamento, esclarecimento médico. Com isso, tem-se que a relaçăo médico-paciente deva ser transparente uma vez que o paciente deposita no profissional a confiança para o tratamento.

Sgreccia refere que o médico é o profissional eleito livremente pelo paciente ou sua família para atuar na prevençấo ou tratamento de uma doença, enquanto que de outro lado, o paciente é o protagonista da administraçăo de sua saúde. (SGRECCIA, 2009, p.344). Entretanto, percebe-se nessa relaçáo que o médico dispóe de conhecimentos técnicos e está habituado a conviver com a dor do outro, enquanto que o paciente devido à doença, está fragilizado.

Sâo vértices diversos de vivência da doença, do ponto de vista do paciente sujeito de intervençôes e do ponto de vista médico que acompanha e trata a doença. A relaçâo entre ambos restou ainda mais distanciada com a especializaçăo dos saberes, o desenvolvimento tecnológico e pela lógica capitalista, quando o corpo do homem passa a ser o âmbito de implementaçăo das tecnologias. (MABTUM, OZAKI e PENNA, 2012). 
Nesse aspecto, como o paciente vulnerável e frágil pode deliberar sobre tratamentos médicos? Poderia frustrar o tratamento recusando submeter-se a ele? Nota-se a importância do cumprimento do dever do médico de esclarecer, auxiliando a pessoa enquanto ela ainda tem autonomia, isto é, enquanto năo estiver debilitada pela doença ou abatida pelos efeitos dos tratamentos. Desse modo, a pessoa pode compreender a circunstância de seu diagnóstico e pensar sobre as formas de tratamento, escolhendo aquelas que condizem com seu íntimo e que serâo registradas em uma diretiva antecipada de vontade - no testamento vital.

Ao analisar o serviço médico enquanto contrato de prestaçáo de serviços, as partes devem cumprir com a boa-fé objetiva que está fundada em deveres como “honestidade, na retidăo, na lealdade e na consideraçâo para com os interesses do outro contraente, especialmente no sentido de náo lhe sonegar informaçóes relevantes a respeito do objeto e conteúdo do negócio". (GONÇALVES, 2012, p. 701).

Caracteriza-se em diretriz de todo e qualquer contrato e, no que concerne à relaçăo médico-paciente, a partir da confiança que deve existir entre ambos, a referida cláusula garante o respeito mútuo, a informaçăo acerca dos tratamentos e procedimentos médico-cirúrgicos, as possibilidades de êxito do tratamento ou procedimento, e ainda, os riscos a que a pessoa estará sujeita.

Denota-se a partir do cumprimento da boa-fé, uma relaçâo verdadeiramente transparente entre médico e paciente mediante o cumprimento de tais deveres e, esclarecido acerca da situaçăo em que se encontra o paciente pode em sua autonomia, deliberar sobre o melhor tratamento médico, ou ainda, o que autoriza à ciência, por meio dos profissionais de saúde, possam promover em seu corpo.

Acrescenta Borges que, o desrespeito médico às escolhas do paciente devidamente esclarecido à recusa de tratamento, caracteriza cárcere privado, constrangimento ilegal e ainda, lesóes corporais, de acordo com o caso. (BORGES, 2001). Nesse sentido, o paciente tem o direito de ser informado sobre os riscos e benefícios quanto às terapias aplicáveis decidindo de forma livre sobre os rumos de sua doença.

Tem-se assim, a consagraçăo do princípio bioético da autonomia da vontade. Nesses rumos, Barchifontaine destaca

o princípio da autonomia ou respeito às pessoas consiste em reconhecer o direito de escolha das pessoas, a autonomia quanto a sua vontade e de seus atos. 0 médico deve respeitar a vontade do paciente em submeter - se ou náo a determinado tratamento médico. (BARCHIFONTAINE, 2007, p.77).

O autor explica ainda, que do referido princípio decorre a demonstraçấo da vontade do paciente por meio do termo de consentimento informado e a substituiçấo da tomada de decisâo do paciente quando este năo tiver condiçóes de fazê-lo. Assim, surge como reflexo da autonomia o termo de consentimento livre e esclarecido como instrumento assinado pelo paciente em que constam todos os esclarecimentos acerca do procedimento e/ou tratamento a que esteja se submetendo. Trata-se de garantia constitucional prevista no art. $5^{\circ}$, XIV e no art.22 do Código de Ética Médica.

Questăo preocupante é a verificada quando a pessoa é incapaz de exprimir sua vontade năo podendo dar seu consentimento ou impedindo tratamentos/ procedimentos. Diante da dúvida quanto às decisóes dos familiares é que desponta o testamento vital 
como alternativa de manutençăo da vontade da pessoa que deve ser respeitada pelo médico independentemente da vontade dos familiares.

Verifica-se com o testamento vital que o médico passa a ser um conselheiro pois a escolha do tratamento é exclusiva do paciente a partir das orientaçóes prestadas pelo profissional médico. A este năo é permitido violar as determinaçōes do paciente, ainda que este năo possa manifestar sua vontade de modo que à família, cumpre respeitar e fazer cumprir as decisóes do paciente sobre os tratamentos dispensados no final de sua vida, conforme pode ser verificado a seguir.

\section{TESTAMENTO VITAL COMO DIRETIVA ANTECIPADA DE VONTADE}

O desenvolvimento da ciência e as conquistas tecnológicas têm promovido modificaçōes profundas na vida das pessoas e em sua qualidade de vida, entretanto, também têm gerado polêmica no que concerne à possibilidade de prolongamento artificial da vida humana. Nesse aspecto, os conhecimentos científicos empregados para prolongar a vida do paciente terminal săo meios de violaçấo da dignidade do paciente, ao invés de serem garantidores da dignidade da pessoa humana.

Na tentativa de prolongar a vida dos pacientes terminais, até mesmo por vontade dos familiares que encontram dificuldades no processo de despedida do paciente, os profissionais de saúde têm empreendido tratamentos para o prolongamento do processo de morte. É a chamada obstinaçâo terapêutica, compreendida como "la utilización desproporcionada de medios tecnológicos para prolongar artificialmente la vida biológica de un paciente con una enfermedad irreversible o terminal". (GONZÁLEZSERNA, 2008, p.196).

As consequências da obstinaçăo terapêutica para a pessoa doente e sua família costumam ser muito negativas uma vez que surgem de um sofrimento desnecessário provocado pela própria medicina. Constatado tal sofrimento, questiona-se se a vida é um bem que deva ser preservado a qualquer preço. Deve prevalecer o desejo da família de garantir sobrevida ao paciente quando nâo há possibilidade de cura?

A pergunta lançada ao leitor, remete à reflexăo sobre os momentos derradeiros da vida e ao modo como o prolongamento da vida tem oportunizado a violaçâo da dignidade da pessoa humana.

Diante desse cenário de incerteza é que surgem as diretivas antecipadas (advanced care documents) oriundas da experiência norte-americana ${ }^{3}$ e que consistem em um conjunto de instruçôes sobre futuros cuidados médicos implementados em uma pessoa que esteja incapaz de expressar sua vontade. De acordo com a mesma legislaçấo, as diretivas antecipadas seriam gênero de documentos de manifestaçâo de vontade para tratamentos médicos, enquanto que o testamento vital (living will) e o mandato duradouro (durable power attorney) seriam espécies.

3 Aprovada em 1991, a lei federal Patient Self Determination Act, reconhece o direito à autodeterminaçáo do paciente, como o próprio nome da lei refere. Disponível em http://thomas.loc.gov/cgi-bin/fquery/ z?c101:H.R.5067. Acesso em 12.mar.2017. 
Com relaçăo ao último, caracteriza-se em instrumento pelo qual se institui um procurador de saúde, que decidirá em nome do paciente nas hipóteses em que este năo puder fazê-lo. Segundo Dadalto, constitui-se no instrumento pelo qual o paciente nomeia um ou mais procuradores que deverâo ser consultados pelo médico em caso de incapacidade definitiva ou náo, do paciente. Tudo a partir do que este houver disposto como vontade prévia. (DADALTO, 2013).

Por sua vez, o testamento vital constitui-se em declaraçáo de vontade para o fim da vida. (DADALTO, 2013). Percebe-se assim, o alcance mais amplo do mandato duradouro sendo ainda possível, que as duas diretivas coexistam em um mesmo instrumento.

O testamento vital é caracterizado por Borges como:

documento em que a pessoa determina, de forma escrita, que tipo de tratamento ou năo tratamento deseja para a ocasiăo em se encontrar doente, em estado incurável ou terminal, e incapaz de manifestar sua vontade. Visa-se, com o testamento vital, a influir sobre os médicos no sentido de uma determinada forma de tratamento ou, simplesmente, no sentido do náo tratamento, como uma vontade do paciente que pode vir a estar incapacitado de manifestar sua vontade em razâo da doença. (BORGES, 2001, p.284).

Nesse mote, convém esclarecer qual a relaçâo existente entre este documento e o testamento, declaraçăo de vontade conhecida no direito sucessório. O termo testamento vital surge como uma aproximaçăo, na medida em que consiste em manifestaçăo de vontade formulada por um agente capaz; deve ser prestado de forma livre e espontânea, sem vícios de consentimento; ainda, constitui-se em um ato passível de revogaçăo ou alteraçăo a qualquer tempo e a incapacidade superveniente do agente nâo inviabiliza o teor da declaraçâo.

Nota-se o que distancia os dois institutos: o caráter patrimonial presente apenas no testamento cível, dado que no testamento vital existem deliberaçôes acerca de tratamentos médicos em caso de terminalidade de vida. Assim, enquanto o primeiro produz efeitos pos mortem, o segundo produz efeitos em vida, na fase terminal do testador.

A partir disso, compreende-se o testamento vital como uma declaraçáo escrita da vontade de um paciente acerca dos tratamentos aos quais năo deseja ser submetido, caso năo possa exprimir sua vontade. Destaca-se o caráter de incapacidade temporária ou de terminalidade de vida, circunstâncias em que a pessoa perde a capacidade de comunicaçấo e expressăo de suas vontades.

O testamento vital surgiu nos Estados Unidos, ao final da década de 60 quando a Sociedade Americana para a Eutanásia propôe no ano de 1967, um "documento de cuidados antecipados" em que a pessoa registraria sua vontade acerca de tratamentos e intervençôes médicas de manutençâo da vida. Dadalto refere que em 1969, Luiz Kutner elaborou o primeiro modelo de Living Will alicerçando as bases do documento. (DADALTO, 2013, p. 96).

Em 1976, surgiu a primeira judicializaçấo acerca do tema quando Karen Ann Quinlan, uma americana com vinte e dois anos de idade entrou em coma e, diante da irreversibilidade do caso, seus pais solicitaram a retirada do respirador. Em razáo da recusa médica em cumprir com a vontade da família, os pais da paciente ajuizaram açăo requerendo a suspensâo do esforço terapêutico dado que em conversas anteriores 
ao coma a paciente teria referido seu desejo de năo ser mantida ligada a aparelhos. Conforme relata Dadalto, o pedido foi negado em primeira instância mas deferido na Suprema Corte de New Jersey. A paciente viveu ainda por nove anos falecendo em decorrência de uma pneumonia e sem ajuda de respiradores. (DADALTO, 2013, p. 96).

Contudo, quais tratamentos podem ser dispensados pelo paciente quando a vida está em risco? Poderia a pessoa por meio do referido instrumento impedir que os profissionais de saúde o atendam de modo a salvar-lhe a vida? Se é difícil pensar sobre a morte mais ainda o é, quando se percebe o modo como ela tem acontecido, notadamente quanto à manutençấo artificial da vida e o prolongamento do processo de morte. Assim, de acordo com suas próprias convicçóes, de acordo com os valores morais e espirituais, a pessoa poderia eleger os chamados cuidados paliativos ou ordinários e a morte em seu devido momento, dispensando toda forma artificial de manutençăo da vida alcançada com os tratamentos extraordinários.

Nesse particular, a literatura refere os cuidados paliativos como sendo todos os cuidados em que é privilegiada a qualidade de vida do paciente terminal até o seu momento final. (CONSELHO FEDERAL DE MEDICINA, 2018). Consistindo em tratamentos ordinários os medicamentos para alívio da dor, oferecimento de oxigênio e todo atendimento de ordem psicológica e espiritual ao paciente e sua família. (DADALTO, 2013). De outra banda, Beauchamps e Childress, referem como tratamentos fúteis ou extraordinários aqueles que náo trazem benefício real ao doente terminal, uma vez que a morte é inevitável. (BEAUCHAMP e CHILDRESS, 2002).

Costuma-se averiguar, caso a caso, a futilidade do tratamento, entretanto, a literatura tem referido como exemplos de atendimentos extraordinários em saúde a internaçăo em Unidades de Tratamento Intensivo - UTIs, a traqueostomia, a ventilaçăo mecânica, a oxigenaçăo extracorpórea, técnicas de circulaçáo assistida, tratamentos com drogas vasoativas, antibióticos, diuréticas e derivados sanguíneos. Destaque-se também, procedimentos cirúrgicos e tratamentos como hemodiálise, quando o paciente já se encontra em fase terminal, em que todos os esforços empregados náo seráo capazes de devolver-lhe a saúde ou alguma possibilidade de melhora. (DADALTO, 2013).

De acordo com González-Serna,

cuando se haya decidido limitar el esfuerzo terapeutico siempre habrá que ofrecer unos cuidados integrales de calidad y con carácter paliativo que impliquen el compromiso de alcazar el mayor bienestar posible para el enfermo y família, ayudándoles y acompañándoles tanto humana como profesionalmente en el difícil processo del morir. (GONZÁLEZ -SERNA, 2008, p. 198).

Contudo, verifica-se o testamento vital como instrumento importante de garantia de qualidade de vida quando instalado o processo de morte visto que a pessoa elege os tratamentos que considera dignos e os que recusa. Ressalte-se também, que as disposiçôes acerca dos tratamentos do paciente terminal nâo estăo relacionadas com a abreviatura da vida, mas sim, com a autorizaçáo para o prosseguimento natural da doença e o desfecho digno da existência, conforme orientam as convicçôes pessoais do paciente. 


\section{RECONHECIMENTO, LIBERDADE E AS PERSPECTIVAS PARA 0 TESTAMENTO VITAL NO BRASIL}

A temática em análise implica a compreensăo inicial de que a opçâo pela redaçáo de um testamento vital diz respeito a uma luta por reconhecimento. Trata-se de um esforço para a consagraçáo da autonomia e efetivaçáo da liberdade daquele que realiza as escolhas atinentes aos tratamentos médicos ofertados para uma dada enfermidade.

Nessa linha, a investigaçăo resgata o projeto de autonomia de Castoriadis, para quem a sociedade autônoma só pode despertar a partir de indivíduos igualmente autônomos. Por tal viés, tem-se uma via de măo dupla em que a autonomia dos indivíduos é propiciada por uma sociedade democrática e autônoma. (CASTORIADIS, 2000, passim).

O autor ainda destaca que a partir da constituiçăo de uma sociedade política surge espaço para a práxis, compreendida como "[...] fazer no qual o outro ou os outros sâo visados como seres autônomos e considerados como agentes essenciais do desenvolvimento de sua própria autonomia". (CASTORIADIS, 2000, p. 94). Com isso, percebe-se o desenvolvimento dinâmico da sociedade alimentado pela contribuiçâo dos indivíduos autônomos para a viabilizaçăo de espaços públicos qualificados.

Nessa esteira, Bauman relaciona sua compreensăo sobre o indivíduo autoconstituído, resultado de um processo amplo de construçáo da identidade. Para ele, a construçâo da identidade do indivíduo é delineado ao longo de toda a sua história, de modo que se verifica o constante desafio da identificaçâo de si próprio, inexistindo um termo final para sua conclusăo. Assim, a sociedade que tem como principal característica a autonomia, é produto da construçăo democrática do coletivo autônomo e, a partir de cada indivíduo autônomo.

Quando escreve a obra Em busca da política, apresenta a política como arte no sentido de permitir a libertaçăo dos indivíduos capacitando-os a estabelecer seus limites individuais e coletivos. Nesse ínterim, aponta como ideia central a construçáo da liberdade individual a partir do trabalho coletivo, ou seja, só pode ser assegurada e garantida coletivamente. (BAUMAN, 2000, p.15).

Ademais, ainda ressalta a garantia de liberdade como um dever de uma boa sociedade, nâo apenas no sentido de assegurar aos indivíduos estarem livres de qualquer coaçâo, mas também de serem capazes de realizar coisas a partir de sua própria liberdade. Nestes termos, "significa primordialmente poder influenciar as condiçóes da própria existência, dar um significado para o 'bem comum' e fazer as instituiçóes sociais se adequarem a esse significado". (BAUMANN, 2000, p. 112).

Em tais rumos, a afirmaçăo do direito de liberdade na escolha e recusa de tratamentos médicos nos momentos derradeiros da vida vem ao encontro de um novo imaginário social, como apontou Cornelius Castoriadis fundado na emancipaçăo e autonomia.

Nesse sentido, a afirmaçăo do direito de liberdade implica a definiçăo anterior sobre liberdade. De acordo com a definiçăo de Abbagnano, a liberdade pode ser compreendida pela possibilidade de autodeterminaçáo quando verificada a ausência de condiçôes e de limites; por outro viés, ainda é vislumbrada como a possibilidade de escolha, sujeita aos limites das liberdades do outro. Nesses termos, a liberdade é referida como sendo condicionada e limitada, assumindo diversos interpretaçóes como no campo metafísico, da moral, da política e da economia. (ABBAGNANO, 2007, p.606). 
A liberdade constitui-se em um dos importantes fundamentos do Estado Democrático de Direito. Caracteriza-se pela possibilidade de autodeterminar, realizar escolhas e viabilizar a realizaçâo projetos atinentes à esfera privada. Na temática de estudo proposta, reconhecer o outro como autor de sua jornada denota a consagraçấo da liberdade, de acordo com a teoria hegeliana do reconhecimento recíproco, dado que aspiraçấo à liberdade atua no sentido de propiciar a interaçấo entre as pessoas que vislumbram suas açôes de modo complementar. (HEGEL, 2007). Nesse aspecto, nas aspiraçóes do outro tidas como componente do mundo externo encontra-se que lhe permite colocar em prática objetivamente as metas estabelecidas por ele mesmo.

Denota-se entâo, o reconhecimento vinculado ao processo de evoluçăo moral a partir da normatizaçăo que gera reconhecimento intersubjetivo com as mudanças nas concepçôes de honra e estima social. (MATTOS, 2006, p.96).

Assim, a concretizaçăo da autonomia de uma pessoa passa a ser vislumbrada quando existe reconhecimento por parte dos outros, o que gera reconciliaçăo recíproca e uma interaçâo dinâmica a ponto de propiciar o surgimento de uma nova eticidade, fundada na confirmaçăo das identidades. Veja-se:

Na medida em que sou reconhecido por um outro sujeito em minhas capacidades e propriedades, se, por um lado, eu me reconcilio com o outro sujeito, por outro, eu aumento a minha percepçâo sobre minhas particularidades e descubro novas especificidades, novas fontes de minha identidade que necessitam novamente ser reconhecidas. Minha identidade ganha uma nova dimensăo alcançando uma nova etapa de eticidade que precisa ser confirmada. (MATTOS, 2006, p.21).

Nota-se entăo, que o reconhecimento por parte do outro torna-se importante para a consagraçấo da autonomia, o que é compreendido na teoria hegeliana como reconhecimento recíproco. (HEGEL, 2007, p. 151). Baseado nessa teoria, Honneth destaca que a honra e a dignidade de uma pessoa estâo relacionadas com a estima social verificada pela com a possibilidade de auto-realizaçâo propiciada pela atribuiçấo de um valor social acerca das capacidades. (HONNETH, 2003, p.217). E destaca,

A aspiraçăo à liberdade deixa de ser um elemento da experiência puramente subjetiva no momento em que o sujeito se encontra com outros sujeitos cujos objetivos se comportam de maneira complementar aos próprios, uma vez que agora o ego pode ver, nas aspiraçóes da outra parte na interaçăo, um componente do mundo externo que lhe permite colocar em prática objetivamente as metas estabelecidas por ele mesmo. (HONNETH, 2015, p.85-86).

Assim, enquanto instrumento de efetiva consagraçâo da vontade do paciente terminal, o testamento vital e seu reconhecimento importa em verdadeira estima social pelo respeito à dignidade daquele que mediante esclarecimento médico e autonomia, já pré-determinou os tratamentos que permite e rejeita em seus momentos finais.

A partir do exposto, é possível destacar algumas reflexóes acerca das perspectivas para a temática no Brasil. Inicialmente, cumpre ressaltar que a matéria de estudo nesta investigaçăo nâo tem correspondente legislativo específico no Brasil. Ainda que o Código Civil enuncie em seu artigo $n^{\circ} 15$, quanto aos direitos da personalidade que "ninguém pode ser constrangido a submeter-se, com risco de vida, a tratamento médico ou a intervençâo cirúrgica". O dispositivo deve ser interpretado ampliativamente pois, nos casos em que náo há risco de vida o disposto também deve ser assegurado. 
No âmbito do Conselho Federal de Medicina a Resoluçăo n¹995/2012, dispôe sobre as diretivas de vontade antecipadas do paciente, determinando que em năo havendo a possibilidade de comunicaçăo deste, o médico deve atender às diretivas antecipadas de vontade que năo contrariarem os preceitos do Código de Ética Médica.

Nesse mote, a resoluçâo supra contribuiu significativamente para o debate dado que com tem força de lei dentre os médicos ao ser proveniente de órgâo de classe. Outro aspecto está relacionado a crescente procura pelo registro de diretivas antecipadas por cidadăos interessados em resguardar das decisóes de familiares ou terceiros seus momentos derradeiros. (DADALTO, TUPINAMBÁS e GRECO, 2013).

Para elucidar o referido a pesquisa demonstra o caso do idoso Joâo Carlos Ferreira, idoso e usuário-morador do Hospital Colônia Itapuá, em Porto Alegre. O Ministério Público ingressou com pedido de alvará judicial no ano de 2013, com o intuito de suprir a vontade do idoso, verificado que o pé esquerdo de Joăo estava necrosando em virtude de uma lesăo sofrida em 2011, de modo a ser perceptível o "emagrecimento progressivo e anemia acentuada resultante do direcionamento da corrente sanguínea para a lesâo tumoral, motivo pelo qual necessita amputar o membro inferior, sob pena de morte por infecçăo generalizada". (BRASIL, 2018).

Entretanto, conforme laudos médicos, o idoso năo apresentava sinais de demência, de modo que em primeira instância o pedido foi indeferido a partir do argumento de que o paciente à época era pessoa capaz podendo escolher os rumos de sua vida sabendo das consequências de seu agir. O juízo ainda reiterou que năo cabe "ao Estado tal interferência, ainda que porventura possa vir a ocorrer o resultado morte."(BRASIL, 2018).

Com tais resultados, o Ministério Público apresentou apelaçâo, enfatizando que o idoso corria risco de morte em virtude de infecçáo generalizada caso năo fosse realizada a amputaçăo, advogando nâo ter o paciente "condiçōes psíquicas de recusar validamente o procedimento cirúrgico, porquanto apresenta um quadro depressivo, conforme os laudos médicos juntados aos autos". Nesse sentido, esboçou tese no sentido de prevalecimento do direito à vida, constitucionalmente indisponível e inviolável para o deferimento do pedido de amputaçấo, ainda que contra a vontade do idoso.

O recurso foi desprovido por unanimidade. O desembargador relator, Irineu Mariani destacou ser a vida direito garantido constitucionalmente deve ser interpretado conjuntamente com a garantia de dignidade da pessoa humana, isto é, o Estado tutela a "vida com dignidade ou razoável qualidade". Nessa senda, restou elucidada a tese de que a Constituiçấo Federal "institui o direito à vida e nâo o dever à vida", razâo pela qual năo seja adequado obrigar uma pessoa a submeter-se à amputaçấo sem o devido consentimento. (BRASIL, 2018).

Outro aspecto, destacado no voto está relacionado à compreensăo da vontade do idoso estar inserida no que é compreendido por ortotanásia, ou seja, nem abreviatura, tampouco o prolongamento do processo de morte. Nesse interim, refere-se à "morte no seu devido tempo, sem prolongar o sofrimento". Ao final, foi proferido acórdăo no sentido do desprovimento do recurso de apelaçấo tendo em vista que Joăo Carlos Ferreira havia feito "seu testamento vital no sentido de năo se submeter à amputaçâo, com os riscos inerentes à recusa". (BRASIL, 2018).

O acórdăo transitou em julgado e nâo existe informaçăo disponível sobre vida ou morte do idoso, após o julgamento. 
Por todo o exposto, percebe-se que o tribunal gaúcho proferiu acórdăo de modo sensível e, ainda que náo exista legislaçăo sobre a matéria demonstra que ordenamento jurídico oferece coesáo suficiente para o reconhecimento do testamento vital enquanto diretiva antecipada de vontade.

\section{CONCLUSÕES}

As demandas deste século desafiam o direito, a doutrina, os intérpretes e, igualmente os julgadores. A evoluçăo das liberdades e a abertura do sistema jurídico para as inovaçóes sociais, assim como a questionável insuficiência de regramentos, inevitavelmente importam em um estranho sentimento de insegurança diante das diversas possibilidades de interpretaçăo acerca dos fatos.

O caso Joăo Carlos Ferreira, neste estudo foi elucidado com o intuito de demonstrar que o debate em torno da dignidade da pessoa humana é a tônica deste século. Se no passado assim como na tradiçâo do direito, a vida constituiu-se em um bem indisponível, contemporaneamente as reflexóes sobre a dimensăo intrínseca da dignidade da pessoa humana e a liberdade de escolha importam na relativizaçăo de tais concepçóes.

O precedente que reconheceu o direito de Joăo Carlos Ferreira em năo permitir a amputaçấo de um pé necrosado reconheceu o direito à morte digna por meio da ortotanásia e, a observância dos cuidados paliativos quando verificada a impossibilidade de cura e a permissáo de viver o tempo devido com dignidade. 0 acórdăo proferido demonstra estima pelo reconhecimento do outro em seus anseios e denota o devido respeito à autonomia do paciente ao conhecer sobre os riscos e benefícios do procedimento a que pode ser submetido.

Nessa linha, verifica-se a projeçâo das liçôes de Hegel e Honneth, na decisăo do julgador de primeiro grau e no acórdáo de modo a investir o Tribunal em verdadeiro canal de demonstraçấo da estima devida ao outro, nas condiçôes em que se encontra. O idoso que decidiu, em sua lucidez viver o tempo devido, teve seu desejo submetido à análise do Tribunal obtendo ao final, o cumprimento de sua vontade o que pode ser vislumbrado como agir sensível para o reconhecimento do outro, ou ainda, acesso à justiça como tradicionalmente referido.

O desconhecimento acerca dos cuidados paliativos e do testamento vital constituem entraves à dignidade do paciente terminal. A inexistência de legislaçăo específica acerca da temática náo prejudica o reconhecimento de deliberaçóes relativas a tratamentos em fase terminal de vida. Nesse aspecto, ressalta-se que o ordenamento jurídico brasileiro oferece coesăo no sentido reconhecer validade desde que a pessoa tenha capacidade plena e năo seja um incapaz superveniente.

Diante de todo o exposto, percebe-se que cumpre ao Estado o importante papel de promover políticas públicas para o reconhecimento dos direitos do paciente, auxiliando a sua divulgaçăo e assegurando na rede de atendimento de saúde os tratamentos paliativos que garantam a máxima qualidade de vida do paciente terminal. 


\section{REFERÊNCIAS}

ABBAGNANO, Nicola. Dicionário de Filosofia. 5.ed. Traduzido por Ivone Castilho Benedetti. Sâo Paulo: Martins Fontes, 2007.

BARCHIFONTAINE, Christian de Paul de. Vulnerabilidade e cuidados. IN: BARCHIFONTAINE, Christian de Paul de; ZOBOLI, Elma Lourdes Campos Pavone. (Orgs.) Bioética, vulnerabilidade e saúde. Sâo Paulo: Sâo Camilo, 2007, p.77. (Bio \&Ética)

BAUMANN, Zygmunt. Em busca da política. Traduzido por Marcus Penchel. Rio de Janeiro: Jorge Zahar, 2000.

BEAUCHAMP, Tom L; CHILDRESS, James F. Princípios de ética biomédica. Trad. Luciana Pudenzi. Săo Paulo: Loyola, 2002.

BORGES, Roxana Cardoso Brasileiro Borges. Direito de morrer de morrer dignamente: eutanásia, ortotanásia, consentimento informado, testamento vital, análise constitucional e penal e direito comparado. In: SANTOS, Maria Celeste Cordeiro Leite. Biodireito: ciência da vida, os novos desafios. Sáo Paulo: Ed. Revista dos Tribunais, 2001. p.283-305.

CASTORIADIS, Cornelius. A instituiçâo imaginária da sociedade. Traduzido por Guy Reynaud. 5.ed. Rio de Janeiro: Paz e Terra, 2000.

CONSELHO FEDERAL DE MEDICINA. Resoluçāo n¹.805/2006. Disponível em http:// www.portalmedico.org.br/resolucoes/cfm/2007/111_2007.htm. Acesso em 07.fev.2018

CONSELHO FEDERAL DE MEDICINA. Resoluçāo n¹995/2012. Disponível em http:// www.portalmedico.org.br/resolucoes/cfm/2012/1995_2012.pdf Acesso em 07.fev.2018

DADALTO, Luciana. Testamento vital. 2.ed. Rio de Janeiro: Lumen Juris, 2013.

DADALTO, Luciana; TUPINAMBÁS, Unaí; GRECO, Dirceu Bartolomeu. Diretivas antecipadas de vontade: um modelo brasileiro. Revista de Bioética (impressa). 2013. Disponível em: http://www.scielo.br/pdf/bioet/v21n3/a11v21n3.pdf Acesso em 22.fev.2018.

GONÇALVES, Carlos Roberto. Direito civil esquematizado. v.1. Săo Paulo: Saraiva, 2012.

GONZÁLEZ-SERNA, José María Galán. Principios éticos em la práctica de los cuidados paliativos: por la humanización de la assistência... p. 193-205. IN: CUESTA, Antonio Ruiz de la (coord). Etica de la vida y la salud: su problemática biojurídica. Sevilla: Universidad de Sevilla, 2008.

HEGEL, Georg Wilhelm Friedrich. Fenomenologia do espírito. 4.ed. Rio de Janeiro: Editora Vozes, 2007. 
HONNETH, Axel. Luta por reconhecimento: a gramática moral dos conflitos sociais. Traduzido por Luiz Repa. Sáo Paulo: Ed.34, 2003.

HONNETH, Axel. O direito da liberdade. Traduzido por Saulo Krieger. Săo Paulo: Martins Fontes, 2015.

MABTUM, Matheus M.; OZAKI, Veridiana T. R.; PENNA, Joâo Bosco. Eutanásia e as manifestaçóes prévias da vontade do paciente. IN: MARCHETTO, Patrícia Borba; BERGEL, Salvador Dario; FALAVINHA, Diego H. S.; RAMPIN, Talita Tatiana Dias (orgs.). Temas fundamentais de direito e bioética. Sáo Paulo: Cultura Acadêmica, 2012.

MATTOS, Patrícia. A sociologia política do reconhecimento: as contribuiçóes de Charles Taylor, Axel Honneth e Nancy Fraser. Sâo Paulo: AnnaBlume, 2006.

ORGANIZAÇÂO MUNDIAL DE SAÚDE. Primer atlas mundial de las necesidades de cuidados paliativos no atendidas. Disponível em http://www.who.int/mediacentre/news/ releases/2014/palliative-care-20140128/es/. Acesso em 24.fev. 2018.

SGRECCIA, Elio. Manual de bioética: fundamentos e ética biomédica. v.1. Traduzido por Orlando Soares Moreira. 3. ed. Sáo Paulo: Loyola, 2009.

SOCIEDAD ESPAN̄OLA DE CUIDADOS PALIATIVOS. Declaración sobre la eutanasia de la Sociedad Española de Cuidados Paliativos. Disponível em http://www.secpal.com/ guiacp/index.php?acc=dos. Acesso em 04.fev.2018.

TRIBUNAL DE JUSTIÇA DO RIO GRANDE DO SUL. Apelaçâo Cível n ${ }^{\circ} 70054988266$ ( $N^{\circ}$ CNJ: 0223453-79.2013.8.21.7000). Disponível em http:/www.tjrs.jus.br. Acesso em 20.jan. 2018.

ZANCANARO, Lourenço. Bioética, Direitos Humanos e Vulnerabilidade. IN: BARCHIFONTAINE, Christian de Paul de; ZOBOLI, Elma Lourdes Campos Pavone. (Orgs.) Bioética, vulnerabilidade e saúde. Sâo Paulo: Sâo Camilo, 2007. (Bio \&Ética) 